\title{
Seasonal and Annual Impacts of Climate Change ON WATERSHED RESPONSE USING AN Ensemble of Global Climate Models
}

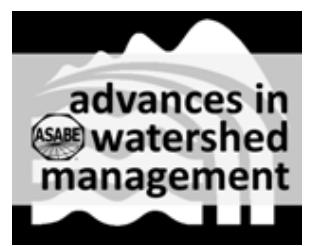

\author{
A. Y. Sheshukov, C. B. Siebenmorgen, K. R. Douglas-Mankin
}

\begin{abstract}
Climate change impacts watershed hydrology and contributes to alteration of hydrologic regimes in streams. However, global climate models (GCMs) operate at spatial and temporal scales that are too large to capture important watershed-scale hydrologic shifts. A method of disaggregating monthly ensemble GCM data into temperature and precipitation data series for daily, watershed-specific hydrologic simulations with SWAT was developed and assessed in the Soldier Creek watershed in northeast Kansas. A stochastic weather generator (WINDS) was employed to produce a baseline scenario (no changes from late 20th century conditions) and two scenarios based on ensemble means of 15 GCMs representing future conditions (A2 storyline) referred to as the 2050 and 2100 scenarios. Future hydrologic regimes exhibited non-linear annual and monthly responses in hydrologic budget components, such as surface runoff, baseflow, and soil moisture, to temperature and precipitation changes. For the 2050 scenario, the combination of higher temperatures along with decreased annual precipitation and increased spring precipitation resulted in higher surface runoff, baseflow, and streamflow in May and June with a longer drought season later in summer. The significant decrease in streamflow, runoff, and baseflow for the 2100 scenario reflected an increase in monthly and annual temperature rather than a direct result of precipitation decline. The 2100 scenario also produced a reduction in low-flow duration, an increase in the number of drought occurrences, and a decrease in flood frequency and duration. In retrospect, use of the stochastic weather generator to temporally downscale monthly GCM results while incorporating site-specific climate variability (such as occurs with convective storms often missed in coarse-resolution GCM data) produced more meaningful analysis of hydrological impacts, which is critical to predicting and understanding the impacts of climate change. Although this method allowed simulation of future-climate shifts based on GCM-simulated monthly shifts, it could not simulate potential shifts in climate patterns within a month, such as changes in transitional probabilities that govern the intensity and distribution of storms with months. In future work, translation of regional climate model responses into WINDS stochastic parameter adjustments will allow more accurate and efficient simulation. The severity of the increased drought and decreased flood responses simulated in this study would not be anticipated by review of precipitation trends alone nor by analysis of annual hydrologic responses alone. Similarly, many critical hydrologic responses reflected interactions between climate variables (e.g., precipitation and temperature) at sub-annual temporal scales, which highlights the need to consider climatic interactions in future studies of climate change impacts.
\end{abstract}

Keywords. Climate change, Global climate model, Hydrologic regime, IPCC, SWAT, Watershed modeling, Weather generator, WINDS.

$\mathrm{U}$ nderstanding the impacts of climate change and variability on watershed hydrologic response is crucial in planning watershed management and mitigation strategies. The Intergovernmental Panel on Climate Change (IPCC, 2000, 2007) developed four carbon emission scenario families (A1, A2, B1, and B2),

Submitted for review in March 2011 as manuscript number SW 9092 ; approved for publication by the Soil \& Water Division of ASABE in November 2011.

Contribution No. 11-253-J from the Kansas Agricultural Experiment Station, Manhattan, Kansas.

The authors are Aleksey Y. Sheshukov, ASABE Member, Research Assistant Professor, Chris B. Siebenmorgen, Graduate Student, and Kyle R. Douglas-Mankin, ASABE Member, Professor, Department of Biological and Agricultural Engineering, Kansas State University, Manhattan, Kansas. Corresponding author: Aleksey Y. Sheshukov, Department of Biological and Agricultural Engineering, Kansas State University, 129 Seaton Hall, Manhattan, KS 66506; phone: 785-532-5418; fax: 785-532-5825; e-mail: ashesh@ksu.edu. which represent several possible sets of changes in the driving forces that can influence future climate. The driving forces include population growth, economic and social development, energy and technology, agriculture and land use emissions, and policies. Global climate models (GCMs) produced as a result of the joint activity of multidisciplinary teams from more than 40 scientific centers around the world (IPCC, 2000) simulate sea, land, and atmospheric interactions according to future carbon emission scenarios.

Outputs from various GCMs represent climate model projections and are available on a monthly-mean scale at the IPCC data center (IPCC, 2010). A study of 21 GCMs (Brunsell et al., 2010) found that seasonal trends of temperature and precipitation for the 21st century (2010 to 2100) in Kansas are significant for all seasons. In northeast Kansas (grid cell 3 in Brunsell et al., 2010), temperature was predicted to increase $0.04^{\circ} \mathrm{C}$ year ${ }^{-1}$ on average in all seasons, and precipitation, although unchanged annually, increased $0.075 \mathrm{~mm}^{\text {year }}{ }^{-1}$ in spring and $0.024 \mathrm{~mm} \mathrm{year}^{-1}$ in winter and decreased $0.06 \mathrm{~mm}$ 
year $^{-1}$ in summer and $0.04 \mathrm{~mm}$ year $^{-1}$ in fall. These projected increases in annual temperature and variation in seasonal precipitation patterns could fundamentally change hydrologic processes (Karl et al., 2009; Siebenmorgen, 2010).

Large-scale GCM projections must be downscaled to finer temporal scales for use in continuous hydrologic models. Currently, GCMs are assumed to do a poor job of capturing smaller-scale, "internally generated" (e.g., convective) storms common in central North America (Gutowski et al., 2010). Stochastic weather generators can be modified to generate future daily values of such climate variables as precipitation, temperature, relative humidity, and wind speed by adjusting historical weather patterns based on predicted future alterations from GCMs (Fowler et al., 2007). However, methods must be developed to capture smaller-scale processes when using future climate adjustments from GCMs.

A number of studies have simulated watershed hydrological responses considering future weather changes either according to GCM projections (Wilby et al., 2004; Zhang et al., 2004; Jha et al., 2006; Siebenmorgen et al., 2010) or using simple shifts in future monthly precipitation and temperature (Varanou et al., 2002; Zhang et al., 2004; Booty et al., 2005; Jha et al., 2006; Zhang et al., 2007; Franczyk and Chang, 2009; Githui et al., 2009). Climate researchers recognize that the use of ensembles of GCMs is preferred to the use of individual GCMs (Winkler et al., 2011b). GCM outputs differ based on the physical model assumptions, modeling algorithms, and temporal and spatial resolution of the models, as well as how the modelers interpreted and represented the carbon emission scenarios. The ensemble-mean approach can represent multiple GCMs as one unified climate scenario.

The methods used to analyze climate change effects have varied according to which parameters were regionally important. Githui et al. (2009) and Zhang et al. (2007) used modeled streamflow, whereas Booty et al. (2005) analyzed water quality, and Varanou et al. (2002) used a combination of water quality, surface flow, lateral flow, and groundwater flow to analyze climate change effects. A sensitivity analysis approach (Somura et al., 2009) studied all combinations of six annual precipitation variation adjustments (from $-20 \%$ to $+30 \%$ in $10 \%$ increments) with three annual temperatureincrease increments $\left(+1^{\circ} \mathrm{C},+2^{\circ} \mathrm{C}\right.$, and $\left.+3^{\circ} \mathrm{C}\right)$. The researchers concluded that river discharge was mostly affected by precipitation variations. Although the effect of temperature was small, it caused a significant increase in annual ET, especially during the winter months. A comprehensive hydrologic modeling analysis of climate change in North America (Jha et al., 2006) used a combination of uniform shifts to conduct a sensitivity analysis as well as multiple GCMs to get monthly temperature and precipitation adjustments for a hydrologic analysis of the upper Mississippi River basin. The analysis found that precipitation shifts had a greater impact on future streamflow than temperature, although the impact of temperature increased as the magnitude of the change increased, and that solar radiation and relative humidity changes had minimal effects on future streamflow.

A few studies were found that presented the hydrologic impacts of multiple GCM results, and a few studies presented methods that captured the stochastic variability of climate while representing future climatic shifts, but no studies combined both these analytical approaches to provide detailed hydrologic responses to future climate variability and change. The objectives of this study were to (1) demonstrate and assess a method to create and analyze an ensemble of temporally disaggregated monthly GCM data that capture smaller-scale processes (e.g., convective storms) in a daily data series, and (2) analyze the impacts of climate scenarios on seasonal watershed processes and responses in a northeast Kansas watershed.

\section{Materials ANd Methods \\ Study AreA}

The selected study area, Soldier Creek watershed (hydrologic unit code 1027010209), is an unregulated watershed of $769 \mathrm{~km}^{2}$ located north of the city of Topeka in northeast Kansas; it drains parts of Nemaha, Jackson, and Shawnee counties (fig. 1). Soldier Creek watershed land use is dominated by pasture $(43 \%)$ and rangeland $(23 \%)$ with $19 \%$ in row crops. Based on watershed assessment information for Jackson County, the cropland, concentrated along the floodplain, is primarily continuous corn; more than $80 \%$ of row crop lands has terraces, and dominant management practices are traditional tillage and no-till. Land uses have remained relatively unchanged since the 1960 s after channelization of the lower portion of Soldier Creek watershed was completed by the U.S. Army Corps of Engineers (Juracek, 2002). The relief generally consists of gently sloping topography with a median slope of $2.7 \%$, and the maximum difference in elevation is $164 \mathrm{~m}$. Soils in this area are generally silt loam and clay loam with a mean permeability around $0.5 \mathrm{~cm} \mathrm{~h}^{-1} ; 35 \%$ of the watershed is in soil hydrologic group D (high runoff potential; mostly located in the northern portion of the watershed), $11 \%$ is in group C (primarily west of the mainstem), and 53\% is in group B (primarily in the eastern portion) (USDANRCS, 2005, 2007). The outlet of the watershed was selected to coincide with U.S. Geological Survey (USGS) gauge station 06889500 at coordinates $39^{\circ} 6^{\prime} 0^{\prime \prime} \mathrm{N}$ and $95^{\circ} 43^{\prime} 29^{\prime \prime} \mathrm{W}$ (USGS, 2009). National Climatic Data Center (NCDC, 2009) cooperative weather station 147007 at the Topeka Airport, about $10 \mathrm{~km}$ southeast of the watershed outlet, was selected as the main weather station for the watershed.

\section{Climate Scenario Generation \\ GCMs and Climate Change Scenarios}

Among 24 available GCMs acquired from the IPCC data center (IPCC, 2010), 15 GCMs were identified as suitable for this study (table 1). Each model uses a unique global grid with the grid cell sizes varying from $\sim 100,000$ to $\sim 700,000 \mathrm{~km}^{2}$. The A2 (high economic growth, low technology development, high population growth) climate change scenario was selected for this study due to a high regionally oriented socioeconomic development in the scenario that has a diverse impact on the environment. For a GCM to be included, it was required to contain results for both a "historical experiment" period from 1961 to 1990, which provides the basis for validation of the GCM-simulated data for the second part of 20th century, and an A2 projection representing future conditions for the 2046-2065 and 2080-2099 periods. These three periods were used to develop three climate scenarios in this study: the baseline scenario, which simulated future climate as unchanged from the historical experiment period, and two climate change scenarios representing GCM results for 2046-2065 (referred to as the 2050 scenario) and 2080-2099 (referred to as the 2100 scenario). 


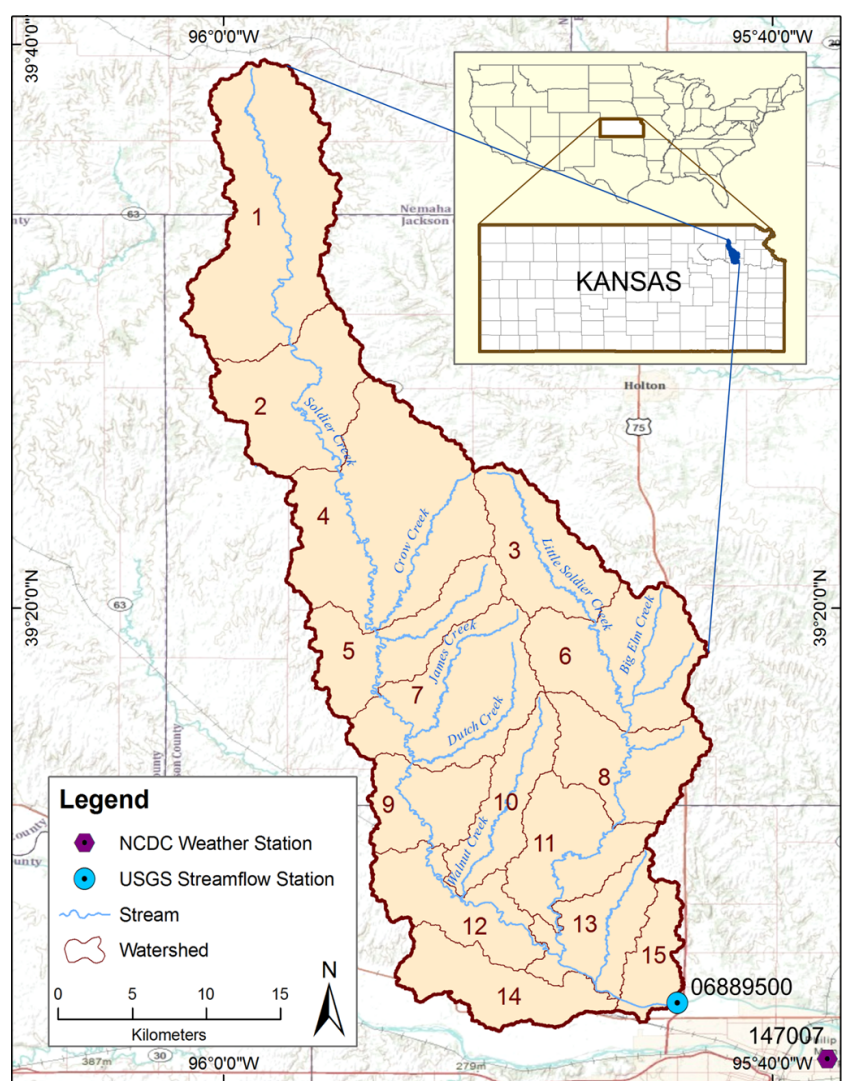

Figure 1. Soldier Creek watershed delineated into 15 subbasins in northeast Kansas. The watershed outlet, shown by a solid circle, is located at USGS gauge station 06889500 .

Data for the grid cell of each GCM (table 1) with the center point closest to the Topeka Airport weather station (fig. 1) were selected, and average monthly values of temperature and precipitation for the three scenario periods were acquired from the IPCC data center (IPCC, 2010). The alterations in climate variables for the 2050 and 2100 scenarios were computed as percentage difference in monthly values from the historical experiment runs.

\section{Time Series Generation with a Stochastic Weather Generator}

Many watershed models simulate hydrologic processes on a continuous daily temporal scale. A common method to downscale monthly temperature and precipitation GCM projections to daily time series is stochastic downscaling using a weather generator (Winkler et al., 2011a). The weather generator used in this study was WINDS (Weather Input for Nonpoint Data Simulation) (Wilson et al., 2006), which simulates many years of weather realization based on statistics computed from daily time series of weather data. A two-step process is used. The first step analyzes historical daily weather records to obtain relevant statistical information. Each climate variable is represented by cosine functions with three harmonics (Wilson et al., 2006). Mean, standard deviation, and skews are computed daily for all non-precipitation data. Since the precipitation climate variable is a discontinuous function, a 28-day interval is used. Transitional probabilities of wet days given that the previous day is wet and given that the previous day is dry are calculated using the cosine fit function (Wilson et al., 2006). The second step uses calculated statistics to generate time series of 11 weather variables. Non-precipitation variables are represented by continuous functions and simulated with a statistical framework of Markov processes. Discrete precipitation events are modeled using a first-order, two-state Markov chain. A transitional probability function is used to identify a rainfall event, and a log-normal probability density function distribution is used to determine precipitation depth for that rainfall event. Crosscorrelations between non-precipitation variables are applied for predicting daily values. This two-step process allows WINDS to produce a continuous daily weather variable time series that closely resembles historical statistics.

This process is excellent at generating weather data based on historical trends, but modifications to WINDS are needed to account for future climate change adjustments. At each step of generating daily variables, the normalizing parameter representing the annual average of the specified variable is scaled according to the monthly GCM shifts, and a new value is generated. The normalizing parameters were scaled for the 2050 and 2100 scenarios but not for the baseline scenario.

Table 1. List of the IPCC AR4 global climate models (IPCC, 2010), grid cell center points, and model resolutions used in the study.

\begin{tabular}{|c|c|c|c|c|c|}
\hline & Model Name & Group & Country & $\begin{array}{c}\text { Cell } \\
\text { (Lat., Long.) }\end{array}$ & $\begin{array}{l}\text { Resolution } \\
\text { (Lat. } \times \text { Long.) }\end{array}$ \\
\hline 1 & CNRM-CM3 & Centre National de Recherches Météorologiques & France & $40.45,264.38$ & $2.80 \times 2.80$ \\
\hline 2 & CSIRO-Mk3.0 & $\begin{array}{c}\text { Australia's Commonwealth Scientific and Industrial } \\
\text { Research Organization }\end{array}$ & Australia & $40.09,264.38$ & $1.875 \times 1.875$ \\
\hline 3 & ECHO-G & $\begin{array}{l}\text { Meteorological Institute, University of Bonn; } \\
\text { Meteorological Research Institute of KMS; } \\
\text { and Model and Data Group at MPI-M }\end{array}$ & $\begin{array}{l}\text { Germany; } \\
\text { Korea }\end{array}$ & $38.94,262.50$ & $3.75 \times 3.75$ \\
\hline 4 & GFDL-CM2 & Geophysical Fluid Dynamics Laboratory & U.S. & $39.00,263.75$ & $2.00 \times 2.50$ \\
\hline 5 & GFDL-CM2.1 & Geophysical Fluid Dynamics Laboratory & U.S. & $39.22,263.75$ & $2.00 \times 2.50$ \\
\hline 6 & GISS-ER & Goddard Institute for Space Studies & U.S. & $37.58,262.50$ & $4.00 \times 5.00$ \\
\hline 7 & UKMO-HadCM3 & U.K. Met Office & U.K. & $40.00,262.50$ & $2.75 \times 3.75$ \\
\hline 8 & UKMO-HadGEM1 & U.K. Met Office & U.K. & $38.75,264.38$ & $1.25 \times 1.875$ \\
\hline 9 & INM-CM3.0 & Institute for Numerical Mathematics & Russia & $40.00,265.00$ & $4.00 \times 5.00$ \\
\hline 10 & IPSL-CM4 & Institut Pierre Simon Laplace & France & $39.30,262.50$ & $2.50 \times 3.75$ \\
\hline 11 & NIES-MIROC3.2medres & National Institute for Environmental Studies & Japan & $40.45,264.38$ & $2.80 \times 2.80$ \\
\hline 12 & ECHAM5/MPI-OM & Max Planck Institut for Meteorology & Germany & $38.23,264.38$ & $2.80 \times 2.80$ \\
\hline 13 & MRI-CGCM2.3.2 & Meteorological Research Institute & Japan & $40.45,264.38$ & $2.80 \times 2.80$ \\
\hline 14 & NCAR-CCSM3 & National Center for Atmospheric Research & U.S. & $39.91,264.38$ & $1.40 \times 1.40$ \\
\hline 15 & NCAR-PCM & National Center for Atmospheric Research & U.S. & $40.45,264.38$ & $2.80 \times 2.80$ \\
\hline
\end{tabular}


A pool of 105-year daily time series was generated for each of the three scenarios. The primary statistics (daily mean and standard deviation) were calculated for each calendar day for each dataset. Each baseline scenario time series had a different degree of agreement with calendar-day statistics from the historical records. The generated dataset with the best fit to the historical statistics had a coefficient of determination $\left(\mathrm{R}^{2}\right)$ greater than 0.95 and was selected for simulation. For future (2050 and 2100) scenarios generated by WINDS, there are no "historical" data to use for best-fit comparison. As a substitute, reference statistics were developed from a 1000-year generated dataset, based on prior analysis that found these long-term (1000 or more years) generated datasets had close agreement $\left(\mathrm{R}^{2}>0.99\right)$ with statistics from historical datasets. Thus, a 1000-year dataset was generated for each future (2050 and 2100) scenario, and the primary statistics calculated from these 1000-year datasets were used to select the best-fit 105-year dataset from the pool of generated 105-year datasets.

\section{WATERSHEd MODELING \\ SWAT Model Setup}

The Soil and Water Assessment Tool (SWAT) version 2005 (Arnold et al., 1998; Neitsch et al., 2004, 2005) was employed to simulate hydrological response to climate change. SWAT is a physically based, watershed scale, continuous simulation model developed by the USDA Agricultural Research Service (ARS) that is used extensively worldwide (Gassman et al., 2007; Douglas-Mankin et al., 2010; Tuppad et al., 2011). SWAT incorporates a set of both physically and empirically based equations to simulate various hydrologic and water quality processes on a daily scale. Based on topography, SWAT delineates the watershed into subbasins. Each subbasin is further subdivided into subareas with homogeneous properties of slope range, land use, and soil type, which are called hydrologic response units (HRUs). Within each HRU, modeling components include hydrology, sediment transport, nutrient transformation, plant growth, soil percolation, and agricultural management. The hydrologic cycle on a given day $j$ is simulated based on the water balance equation within the HRU (all balance variables have units of $\mathrm{mm}$ $\left.\mathrm{H}_{2} \mathrm{O}\right)$ :

$$
S W_{j}=S W_{0}+\sum_{i=1}^{j}(P R-R O-E T-I N-G W)
$$

where $S W$ is the soil water content, $P R$ is the amount of precipitation, $R O$ is the amount of surface runoff, $E T$ is the amount of evapotranspiration, $I N$ is the amount of water entering the vadose zone from the soil profile, and $G W$ is the amount of return flow. The subscript 0 indicates the initial water content at the beginning of the simulations.

This study used the NRCS runoff curve number method with daily adjustment according to soil moisture conditions to estimate surface runoff, the Penman-Monteith method for estimation of evapotranspiration, and the Muskingum method for channel routing. SWAT uses daily weather data (minimum and maximum temperature, precipitation depth, solar radiation, wind speed, and relative humidity) applied uniformly to all HRUs within a subbasin according to the nearest weather station.
A SWAT model was built for Soldier Creek watershed (fig. 1) with 15 subbasins ranging from 100,000 to 200,000 ha delineated using a $30 \mathrm{~m}$ digital elevation model for Jackson, Nemaha, and Shawnee counties (USDA-NRCS, 2009). The stream network was created during the delineation process. Land use data were derived from the National Land Cover Dataset from 2001 (Homer et al., 2004; USDANRCS, 2009), and soil data were derived from the STATSGO data layer (USDA-NRCS, 2005, 2007). An overlap of the three spatial datasets of slope range, land use, and soil was processed with SWAT, and 878 HRUs were generated. Daily maximum and minimum temperature and precipitation data series for three future climate scenarios were prepared with WINDS for 105 years (5 years of model spin-up and 100 years of simulation).

\section{Model Calibration}

The SWAT model for Soldier Creek watershed was calibrated using daily streamflow at the watershed outlet (fig. 1) from USGS gauge station 06889500 (USGS, 2009). The historical daily precipitation and minimum and maximum temperature data series were acquired for the period of 1980 to 1999 from cooperative weather station 147007 (NCDC, 2009). Daily values for other weather variables (solar radiation, relative humidity, and wind speed) were generated by SWAT. Eleven model parameters were adjusted during calibration (table 2). Values of BF_ALPHA and GW_DELAY for baseflow contribution in all subwatersheds were calculated with the method presented by Arnold and Allen (1999). The remaining parameters were iteratively varied over the recommended ranges (table 2) until acceptable statistics were reached. The SWAT model was run from 1980 to 1999 and calibrated using daily streamflow over a 16-year period (1983 to 1999) using $\mathrm{R}^{2}$, Nash-Sutcliffe efficiency (NSE), percent bias (pBias), and difference in daily, monthly, and annual mean and median observed and simulated flows (Moriasi et al., 2007). Final calibration statistics for daily, monthly, and annual streamflow are reported (table 3); monthly results were rated good $\left(\mathrm{R}^{2}, \mathrm{NSE}\right)$ to very good (pBias) according to criteria proposed by Moriasi et al. (2007) and Parajuli et al. (2009a, 2009b).

\section{Intra-AnNual Streamflow Analysis}

Six hydrologic indices were selected for analysis of intraannual streamflow characteristics that are representative of stream alteration: mean annual flow, low pulse count and duration, and high-flow peak, duration, and frequency. Low-

Table 2. SWAT parameters adjusted during the streamflow calibration procedure.

\begin{tabular}{cccc}
\hline Parameter & $\begin{array}{c}\text { Default } \\
\text { Value }\end{array}$ & $\begin{array}{c}\text { Adjustment } \\
\text { Range }\end{array}$ & $\begin{array}{c}\text { Final Adjusted } \\
\text { Value }\end{array}$ \\
\hline SMTMP & 0.5 & -5 to 5 & 2 \\
TIMP & 1.0 & 0 to 1.0 & 0.5 \\
ESCO & 0.95 & 0.01 to 1.0 & 0.8 \\
EPCO & 1.0 & 0.01 to 1.0 & 0.1 \\
SURLAG & 4 & 1 to 12 & 2 \\
GW_DELAY & 31 & 0 to 500 & 27 \\
ALPHA_BF & 0.048 & 0.0 to 1.0 & 0.08 \\
GWQMIN & 0 & 0 to 5000 & 0.01 \\
GW_REVAP & 0.02 & 0.02 to 0.20 & 0.1 \\
REVAPMN & 1 & 0 to 500 & 0.08 \\
RCHRG_DP & 0.05 & 0.0 to 1.0 & 0.1 \\
\hline
\end{tabular}


Table 3. Statistics for the streamflow calibration run.

\begin{tabular}{cccc}
\hline & $\mathrm{R}^{2}$ & NSE & pBias \\
\hline Daily & 0.56 & 0.56 & $5.69 \%$ \\
Monthly & 0.74 & 0.73 & $5.78 \%$ \\
Yearly & 0.88 & 0.84 & $5.69 \%$ \\
\hline
\end{tabular}

flow indices represent droughts, which impact habitat for aquatic organisms and water table levels for phreatic riparian plants. Low pulse threshold is defined by the annual mean flow minus one standard deviation $\left(4.2 \mathrm{~m}^{3} \mathrm{~s}^{-1}\right.$ in this study). Low pulse count is the number of times the daily flow falls below the threshold, and low pulse duration is the mean number of days below the threshold per occurrence, as discussed in IHA (2009). Floods are continuous periods of time when daily flow values exceed the annual mean flow plus one standard deviation and have a peak above $10 \%$ probability of exceedance (or $600 \mathrm{~m}^{3} \mathrm{~s}^{-1}$ in this study). These thresholds were suggested in IHA (2009) and verified by analyzing natural breaks in flood event peak streamflows.

\section{Results AND Discussion}

\section{TEMPORAL DisAgGREgATION}

\section{GCM Historical Experiment Validation}

The range of average monthly temperatures simulated for 1961 to 1990 from 15 GCMs was consistent with the NCDC weather station observations throughout all months (fig. 2b), with monthly means from the $15 \mathrm{GCM}$ ensemble underestimating the means from the NCDC weather station by $1.5^{\circ} \mathrm{C}$ on average $\left(\mathrm{R}^{2}=0.95\right)$. Variation in simulated precipitation among the GCMs was substantially greater (fig. 2a), with standard deviations ranging from $13 \mathrm{~mm}$ in winter months to about $40 \mathrm{~mm}$ in July and August. This variation could have been influenced both by expected monthly variability in precipitation as well as by inconsistency in the area and location covered by the different GCM cells (table 1). Although all GCM cells overlapped the target watershed, they also included areas north, south, east, and west of the watershed in varying proportions, and thus represented slightly different climatic conditions. Comparison of monthly means from the 15 GCM ensemble and the NCDC weather station data re-

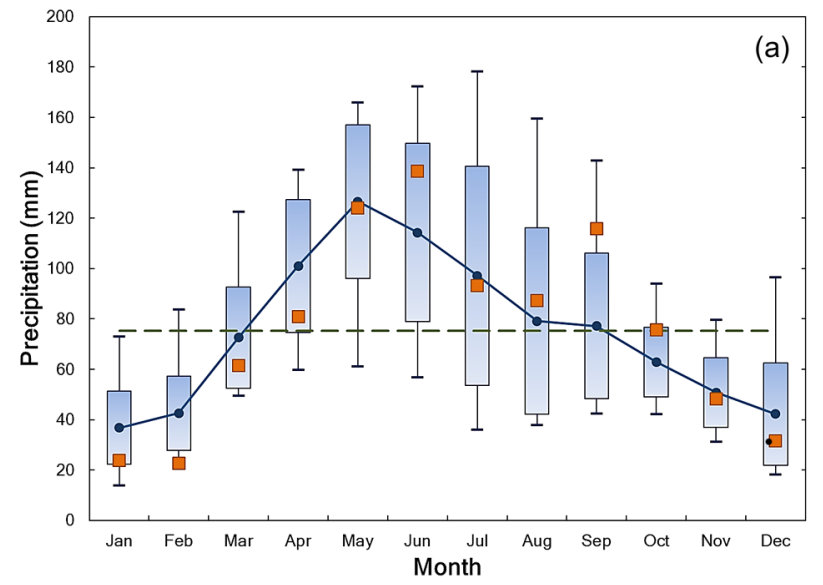

sulted in $\mathrm{R}^{2}=0.78$. The dual peaks in precipitation (June and September) from the NCDC data were not captured by the multi-model GCM dataset. Again, this could reflect that the 15 GCM cells did not represent the same spatial area. In addition, convective storms prevalent in the Midwest are not represented well by GCMs (Brunsell et al., 2010), which likely contributed to the observed variability in simulated precipitation. Nonetheless, the range of monthly GCM results from historical simulations seemed to overlap the monthly mean NCDC data used in this study, indicating a reasonable representation of local monthly mean climate. In addition, the lack of inclusion of convective storms by GCMs was addressed in this study by the use of daily historical distributions of precipitation data (by WINDS), which included convective storms.

\section{Future Climate Trends}

The average change in GCM-simulated precipitation from baseline to the 2050 scenario (fig. 3a) was positive (increased) for spring, fall, and winter, with the greatest increase in May, and was negative (decreased) for summer (June through September). The influence of any under- or overestimation observed in the historical GCM simulations (fig. 2a) were minimal in the analysis of future climate since this analysis focused on relative changes between ensemble-mean GCM results rather than absolute values of GCM results. Thus, the general underestimation by GCMs evident in the baseline (historical) results (fig. 2a) in June and September and overestimation in January through April likely had only minimal influence on the seasonal changes from the baseline GCM precipitation values in figure 3a. The standard deviation among GCMs exceeded $10 \mathrm{~mm}$ in all months, with summer months tending to have the largest variability (>25 mm). Similar seasonal trends in GCM-simulated precipitation changes were observed from the baseline to the 2100 scenario (fig. 3c) but with increased variability among GCMs, particularly for the months of June through September. Mean temperature changes from the baseline increased from $2^{\circ} \mathrm{C}$ to $4^{\circ} \mathrm{C}$ in all months for the 2050 scenario, with the greatest increase in August (fig. 3b). Mean temperature change was even greater for the 2100 scenario, increasing by $4^{\circ} \mathrm{C}$ to $6.5^{\circ} \mathrm{C}$ (fig. $3 \mathrm{~d}$ ).

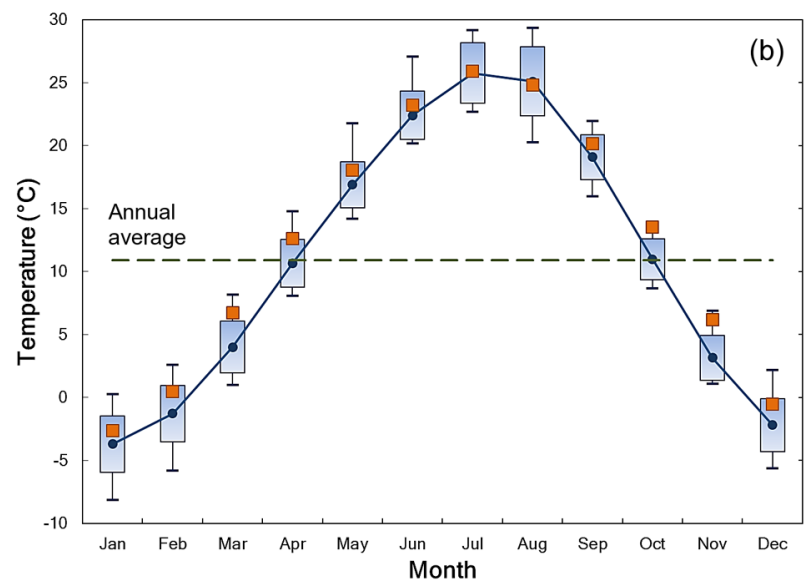

Figure 2. Monthly statistics (mean, \pm 1 standard deviation, maximum, and minimum) of 15 GCMs for (a) precipitation and (b) temperature compared to mean monthly value from historical data (1961-1990) from the NCDC weather station at Topeka Airport, shown as solid squares. Annual averages of $75.3 \mathrm{~mm}$ (precipitation) and $10.9^{\circ} \mathrm{C}$ (temperature) are shown as dashed lines. 

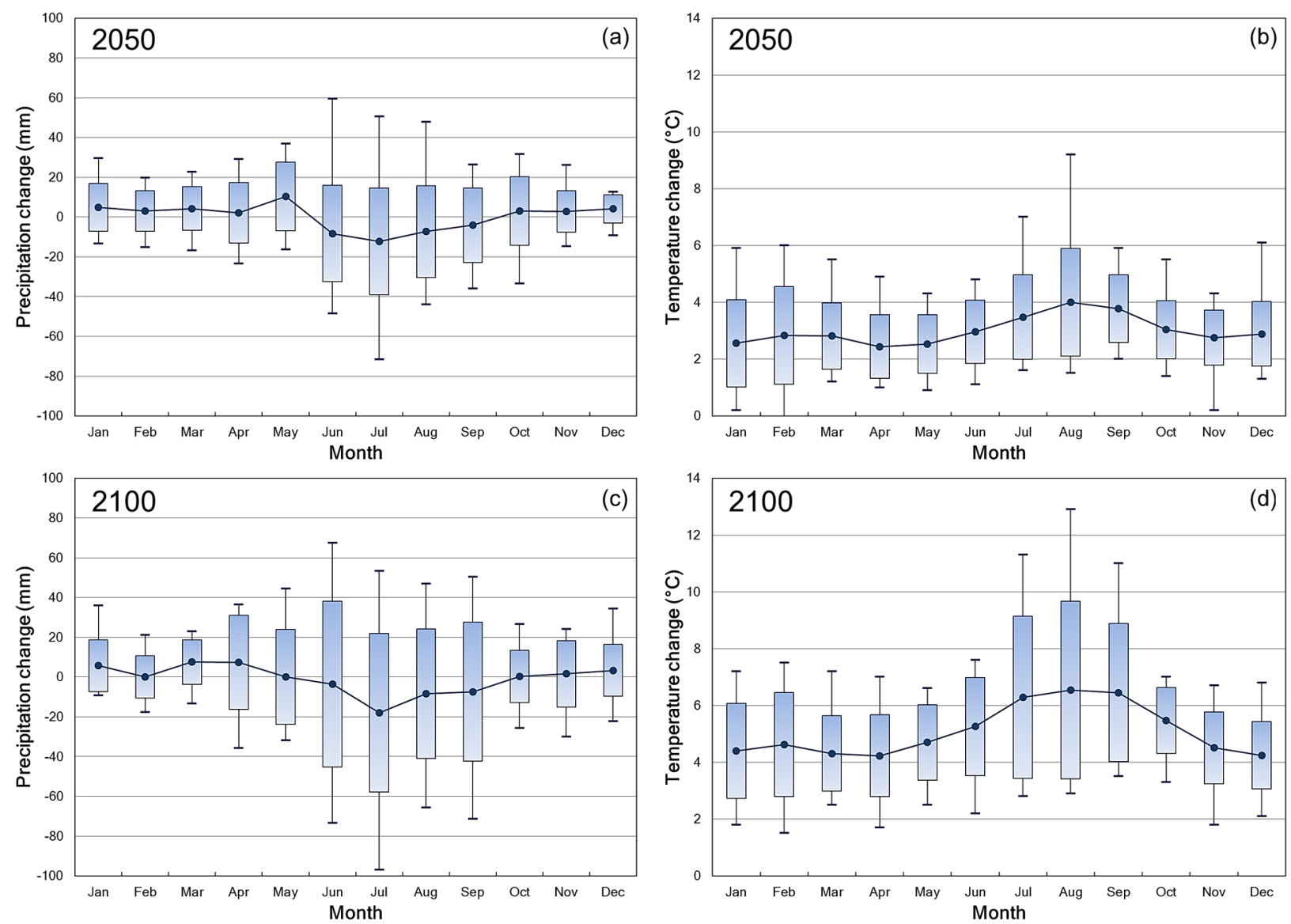

Figure 3. Statistics (mean, \pm 1 standard deviation, maximum, and minimum) of changes in monthly precipitation and temperature compared to the historical experiment period for each GCM for $(a, b)$ the 2050 scenario and (c, d) the 2100 scenario. Annual means of precipitation and temperature changes are $+2.3 \mathrm{~mm}$ and $+3.0^{\circ} \mathrm{C}$ for the 2050 scenario and $-11.3 \mathrm{~mm}$ and $+5.1^{\circ} \mathrm{C}$ for the 2100 scenario.

\section{FUTURE HYDROLOGIC IMPACTS}

Annual precipitation decreased by $5.9 \%$ in 2100 , but streamflow, surface runoff, and baseflow decreased by $17.2 \%$ to $20.7 \%$ because of the large increase in monthly and annual temperatures (table 4). Annual impact on these hydrologic responses in the 2050 scenario was substantially less but positive (1\% to $2 \%$ increases) with only a slight decrease in annual precipitation. The drastic change from slight increases for 2050 to large decreases for 2100 appeared to result from interactions of hydrological processes. For example, in 2050, the $0.5 \%$ decrease in annual precipitation coupled with the $1.2 \%$ decrease in ET could have interacted to cause the simulated increases in surface runoff $(1.0 \%)$ and baseflow (2.2\%). Similarly, the ten times greater decrease relative to 2050 $(5.9 \%)$ in annual precipitation coupled with only a two times greater decrease $(2.4 \%)$ in ET in 2100 could have interacted to cause the simulated decreases in surface runoff $(15.5 \%)$ and baseflow (20.7\%). However, analysis of annual hydrologic results does not capture the important seasonal changes that result from changing climate, and the small annual changes (often less than 2\%) mask the significance of hydrologic response to climate change.

Streamflow increased for the 2050 scenario in May and June, followed by a decrease in August and September (table 4, fig. 4). The increased streamflow in June opposed the decreased precipitation in June and appeared to reflect delayed transmission of the increased April and May precipitation via baseflow in May and June and was related to in- creased infiltration (May) and soil water content (April and May). Surface runoff increased continuously from April to July, with an increase in precipitation in April and May and a decrease in June and July. The increased surface runoff and streamflow in July during the 2050 simulations despite decreased precipitation and baseflow may have been partly related to the decreased ET, infiltration, and soil moisture, which are reflected in the monthly values. An additional influence that is not reflected in the monthly values was several extreme precipitation events in July during 2050 (compared to no extreme events in the baseline scenario) that contributed to streamflow but contributed little to infiltration and baseflow. The $13.9 \%$ (15 mm) decrease in August precipitation during 2050 more than offset a $6.4 \%(6 \mathrm{~mm})$ decrease in ET to cause a $20.4 \%(2.5 \mathrm{~mm})$ decrease in surface runoff. In September, however, a $6.2 \%(6.2 \mathrm{~mm})$ increase in precipitation replenished most (about $10 \mathrm{~mm}$ ) of the soil moisture deficit from August and together with a $2.4 \%(1.5 \mathrm{~mm})$ decrease in ET resulted in a $7.2 \%(1.0 \mathrm{~mm})$ decrease in surface runoff and $21.5 \%(0.5 \mathrm{~mm})$ decrease in baseflow.

Compared to 2050, annual precipitation for 2100 decreased by $5.9 \%$, whereas mean annual streamflow decreased by $17.2 \%$ (table 4 ). Streamflow and surface runoff for 2100 decreased relative to the baseline in all months except April, and baseflow decreased in all months. Decreased by $20.5 \%$ baseflow in June for 2100 (fig. 4) appears disproportionately large relative to a slight decrease of $3.2 \%$ in precipitation and probably reflects a one-month lag of infiltration 
Table 4. Monthly and annual values of the hydrologic balance components specified in equation 1 for the baseline scenario. Data for the 2050 and 2100 scenarios represent percentage changes from the baseline conditions.

\begin{tabular}{|c|c|c|c|c|c|c|c|c|c|c|c|c|c|}
\hline & \multicolumn{12}{|c|}{ Month } & \multirow{2}{*}{$\begin{array}{c}\text { Annual } \\
\text { Mean }\end{array}$} \\
\hline & Jan. & Feb. & Mar. & Apr. & May & June & July & Aug. & Sept. & Oct. & Nov. & Dec. & \\
\hline \multicolumn{14}{|l|}{ Baseline } \\
\hline Precipitation (mm) & 26.6 & 36.3 & 61.0 & 84.7 & 135.7 & 133.5 & 107.8 & 107.9 & 100.4 & 97.3 & 56.3 & 24.1 & 971.5 \\
\hline Streamflow $\left(\mathrm{m}^{3} \mathrm{~s}^{-1}\right)$ & 2.2 & 3.1 & 3.4 & 3.9 & 7.7 & 7.7 & 5.5 & 4.0 & 4.8 & 5.6 & 4.5 & 2.2 & 4.5 \\
\hline Surface runoff $(\mathrm{mm})$ & 5.0 & 8.1 & 8.8 & 9.7 & 23.5 & 20.1 & 14.9 & 12.1 & 14.6 & 15.6 & 9.2 & 2.4 & 12.0 \\
\hline Baseflow (mm) & 2.6 & 2.3 & 3.6 & 4.4 & 5.7 & 7.3 & 4.4 & 2.3 & 2.4 & 4.6 & 5.9 & 4.9 & 4.2 \\
\hline Infiltration (mm) & 2.3 & 5.2 & 8.8 & 10.6 & 16.5 & 13.8 & 5.2 & 3.4 & 5.8 & 10.0 & 8.0 & 2.5 & 7.7 \\
\hline Soil moisture (mm) & 251.5 & 258.5 & 259.9 & 259.4 & 257.5 & 234.4 & 200.6 & 200.7 & 219.8 & 241.7 & 247.0 & 247.1 & 239.8 \\
\hline $\mathrm{ET}(\mathrm{mm})$ & 12.6 & 20.0 & 44.6 & 64.9 & 96.8 & 123.0 & 121.7 & 92.4 & 60.6 & 49.2 & 32.7 & 16.4 & 61.2 \\
\hline Water yield (mm) & 7.5 & 10.2 & 12.2 & 13.8 & 28.6 & 26.9 & 19.2 & 14.3 & 16.9 & 19.9 & 15.0 & 7.4 & 16.0 \\
\hline \multicolumn{14}{|l|}{2050 Scenario } \\
\hline Precipitation & 1.7 & 1.2 & -3.5 & 6.4 & 9.3 & -6.2 & -9.6 & -13.9 & 6.2 & -0.2 & 0.5 & 22.5 & -0.5 \\
\hline Streamflow & 14.9 & -4.1 & -8.7 & 6.0 & 19.3 & 9.7 & 0.6 & -20.1 & -13.6 & 3.7 & -12.8 & 7.4 & 1.3 \\
\hline Surface runoff & 22.2 & -4.0 & -21.4 & 18.3 & 17.2 & 3.7 & 0.4 & -20.4 & -7.2 & 7.1 & -24.6 & 23.2 & 1.0 \\
\hline Baseflow & 7.5 & 7.8 & 10.9 & -9.5 & 27.2 & 14.9 & -12.9 & -27.4 & -21.5 & -11.5 & 3.9 & 2.8 & 2.2 \\
\hline Infiltration & 27.9 & 4.3 & -3.9 & -1.7 & 33.6 & -12.8 & -28.4 & -49.4 & -24.7 & 8.8 & -4.6 & 28.7 & 0.8 \\
\hline Soil moisture & 0.1 & 0.5 & -0.5 & 1.1 & 1.0 & -2.3 & -4.1 & -6.4 & -1.3 & -1.5 & -0.7 & 0.1 & -1.0 \\
\hline ET & 2.6 & 2.9 & 3.0 & -0.4 & 3.6 & 0.6 & -5.0 & -6.4 & -2.4 & -1.8 & -0.3 & -1.3 & -1.2 \\
\hline Water yield & 16.7 & -1.8 & -12.0 & 9.8 & 19.2 & 7.2 & -2.4 & -21.3 & -9.3 & 2.6 & -13.6 & 9.1 & 1.3 \\
\hline \multicolumn{14}{|l|}{2100 Scenario } \\
\hline Precipitation & 7.4 & -5.3 & -7.7 & 7.4 & -10.1 & -3.2 & -19.3 & -11.8 & 1.1 & -13.1 & -14.1 & 50.0 & -5.9 \\
\hline Streamflow & -5.5 & -5.9 & -23.5 & 8.5 & -17.6 & -4.6 & -29.7 & -7.2 & -19.8 & -34.0 & -45.1 & -3.9 & -17.2 \\
\hline Surface runoff & 7.0 & -5.3 & -33.7 & 24.2 & -20.7 & 1.8 & -35.3 & -6.3 & -15.3 & -37.3 & -53.6 & 77.7 & -15.5 \\
\hline Baseflow & -13.0 & -1.6 & -2.7 & -17.5 & -5.4 & -20.5 & -21.2 & -30.3 & -35.0 & -26.5 & -33.7 & -34.6 & -20.7 \\
\hline Infiltration & 17.0 & -4.8 & -14.2 & -5.1 & -11.6 & -14.0 & -34.0 & -48.8 & -21.3 & -30.9 & -42.8 & 8.8 & -17.9 \\
\hline Soil moisture & -0.6 & -0.6 & -1.3 & 0.3 & -2.8 & -3.3 & -6.3 & -6.9 & -4.0 & -4.7 & -4.7 & -1.8 & -2.9 \\
\hline ET & 4.0 & 2.3 & 3.5 & 0.4 & 1.6 & -1.9 & -7.2 & -9.7 & -0.5 & -2.0 & -0.6 & -1.0 & -2.4 \\
\hline Water yield & -0.5 & -4.8 & -25.2 & 11.4 & -17.7 & -3.9 & -31.9 & -9.8 & -18.2 & -34.9 & -45.7 & 1.8 & -16.9 \\
\hline
\end{tabular}
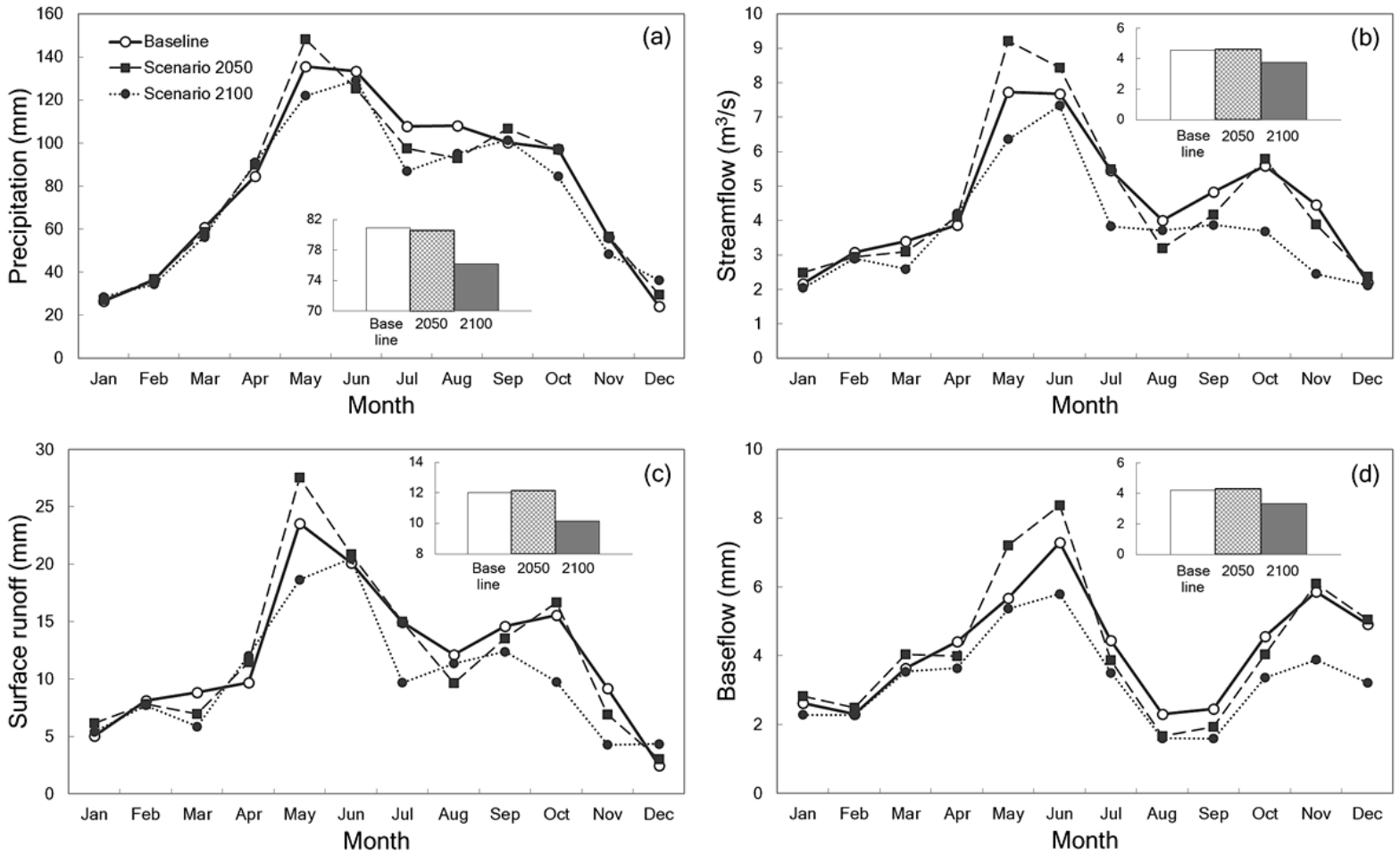

Figure 4. Distribution of monthly average precipitation, streamflow, surface runoff, and baseflow for baseline, 2050, and 2100 scenarios. Annual average values are shown in the insets. 
and surface runoff decreases from May, similar in process to the lagged baseflow increase predicted for 2050 described above.

The changes in monthly hydrologic components were less for 2100 , not due to monthly variations in precipitation but due to the greater influence of increasing monthly temperatures. The 2050 scenario predicted an annual increase of $3.0^{\circ} \mathrm{C}$, but the 2100 scenario projected that increase to be $5.1^{\circ} \mathrm{C}$. As a result, the comparison between these two scenarios was basically a test of the temperature effects.

Soil moisture, important for crop production, decreased on an annual basis by $1.0 \%$ in 2050 and $2.9 \%$ in 2100 . However, monthly decreases in soil moisture peaked at $6.4 \%$ in 2050 and $6.9 \%$ in 2100 (table 4). ET also increased in early spring due to increased ET demand from increased temperatures coupled with adequate soil moisture availability; however, ET decreased in summer due to decreased soil moisture availability from decreased summer precipitation and increased temperature. These decreases in soil moisture during the crop growing season may have critical impacts on crop yields that cannot be inferred from the raw climate change data or the annual hydrologic impact summary values.

\section{INTRA-ANNUAL STREAMFLOW IMPACTS}

Mean annual flow remained nearly unchanged from the baseline to 2050 but decreased by $17.2 \%$ for 2100 (table 5) due to decreased precipitation and increased temperature. Low pulse counts increased by $11.6 \%$ for 2050 and $24 \%$ for 2100 , while low pulse duration decreased by $8 \%$ in both future scenarios. For 2100, flood duration decreased by $34.2 \%$ and frequency decreased by $14.8 \%$. These are considerably larger changes than for 2050, in which flood duration decreased by $4.3 \%$ and frequency remained constant. If floods were subdivided into large floods (peaks $>600 \mathrm{~m}^{3} \mathrm{~s}^{-1}$ ) and small floods (peaks $>350 \mathrm{~m}^{3} \mathrm{~s}^{-1}$ ), then the difference became more pronounced for 2100 . The number of large floods dropped $50 \%$ from the baseline scenario, and the number of small floods increased by $12 \%$. For 2050 , the frequency of small and large floods was close to the baseline and consisted of one large flood every nine years and one small flood every six years. In both future scenarios, the maximum flood peaks increased relative to the baseline.

The increase of streamflow in the late spring and early summer observed in both future climate scenarios, followed by the significant decrease in streamflow in the late summer and early fall (table 4), could have adverse effects on agricultural production. Although crops will have adequate precipitation in the early growing stages, water stress in the late summer may lead to plant stress and increased irrigation demand. The 2100 scenario had similar precipitation but higher temperatures than the 2050 scenario, resulting in similar low

Table 5. Hydrologic indices of the baseline and two future climate scenarios (values in parentheses are percent differences from baseline).

\begin{tabular}{lccc}
\hline & $\begin{array}{c}\text { Baseline } \\
\text { Value }\end{array}$ & $\begin{array}{c}2050 \\
\text { Scenario }\end{array}$ & $\begin{array}{c}2100 \\
\text { Scenario }\end{array}$ \\
\hline Mean annual flow $\left(\mathrm{m}^{3} \mathrm{~s}^{-1}\right)$ & 4.50 & $4.60(1.3 \%)$ & $3.80(-17.2 \%)$ \\
Low pulse count $\left(\mathrm{year}^{-1}\right)$ & 6.00 & $6.70(11.6 \%)$ & $7.40(24.0 \%)$ \\
Low pulse duration $($ days $)$ & 16.00 & $14.70(-8.0 \%)$ & $14.70(-8.0 \%)$ \\
Flood peak $\left(\mathrm{m}^{3} \mathrm{~s}^{-1}\right)$ & 777.40 & $861.70(10.8 \%)$ & $844.30(8.6 \%)$ \\
Flood duration (days) & 61.58 & $58.90(-4.3 \%)$ & $40.53(-34.2 \%)$ \\
Flood frequency $\left(\mathrm{year}^{-1}\right)$ & 0.27 & $0.27(0.0 \%)$ & $0.23(-14.8 \%)$ \\
\hline
\end{tabular}

pulse duration but greater low pulse count as well as a reduction in flood duration and frequency.

\section{Conclusions}

Analysis of two future climate scenarios (2050 and 2100) underscored the importance of evaluating possible monthly or seasonal shifts in addition to annual evaluations, as annual synoptic analysis can mask important changes to the hydrologic budget. Assessment of the effects of climate change must not be limited to the forcing functions (temperature, precipitation, and carbon dioxide) but must instead consider important hydrologic response parameters, such as soil moisture, runoff, and streamflow. To the extent that watershed planners make decisions based on hydrologic response parameters, translating GCM results into the hydrologic parameters that inform land-management decisions is critical. Further research is needed both in the analysis of hydrologic impacts of climate change as well as the understanding of which hydrologic parameters are used by landscape and watershed managers in their land-use decisions.

The severity of the increased drought and decreased flood responses simulated in this study would not be anticipated by review of precipitation trends alone nor by analysis of annual hydrologic responses alone. Many of the critical hydrologic responses reflected interactions of climate variables (e.g., precipitation and temperature) at sub-annual temporal scales. Thus, climatic interactions should be considered in studies of climate change impacts on hydrology.

Compared to simply incorporating GCM data (as done in some previous climate change impact studies), the WINDS stochastic weather generator was able to better simulate the presence of "internally generated" (i.e., convective) storms by the use of probability distributions from historical data. Although this improved method allowed simulation of future climate shifts based on GCM-simulated monthly shifts, it could not simulate potential shifts in climate patterns within a month, such as changes in transitional probabilities that govern the intensity and distribution of storms with months. Such analysis may be possible using regional climate models to dynamically downscale GCMs. Regional climate models capture feedbacks leading to disproportional increases in storm intensity and timing, which are critical to hydrologic forecasting. Translation of regional climate model responses into WINDS stochastic parameter adjustments will allow more accurate and efficient simulation of future local climates for watershed analyses.

Results of this study also suggest that assessment of climate variability may require more than 100 years of hydrologic analyses. For example, assessment of the impact of climate change on flood frequency requires long-term hydrologic analysis; a 100-year flood analysis would require the results of multiple 100-year periods to provide accurate representation. This also suggests the importance of a stochastic weather generator, as used in this study, in development of future climate scenarios to capture various temporal progressions of precipitation events that are consistent with the established future precipitation probability distributions. In addition, further research is needed to define how future precipitation distributions differ from historical patterns. 


\section{ACKNOWLEDGEMENTS}

Financial assistance was provided by the Kansas State Water Plan and U.S. EPA Section 319 NPS Pollution Control Grant through a grant from the Kansas Department of Health and Environment.

\section{REFERENCES}

Arnold, J. G., and P. M. Allen. 1999. Automated methods for estimating baseflow and groundwater recharge from streamflow records. J. American Water Resour. Assoc. 35(2): 411-424.

Arnold, J. G., R. Srinivasan, R. S. Muttiah, and J. R. Williams. 1998. Large-area hydrologic modeling and assessment: Part I. Model development. J. American Water Resour. Assoc. 34(1): 73-89.

Booty, W., D. Lam, G. Brown, O. Resler, and L. Leon. 2005. Modelling changes in stream water quality due to climate change in a southern Ontario watershed. Canadian Water Resour. J. 30(3): 211-226.

Brunsell, N. A., A. R. Jones, T. L. Jackson, and J. J. Feddema. 2010. Seasonal trends in air temperature and precipitation in IPCC AR4 GCM output for Kansas, USA: Evaluation and implications. Intl. J. Climatol. 30(8): 1178-1193.

Douglas-Mankin, K. R., R. Srinivasan, and J. G. Arnold. 2010. Soil and Water Assessment Tool (SWAT) model: Current developments and applications. Trans. ASABE 53(5): 1423-1431.

Fowler, H. J., S. Blenkinsop, and C. Tebaldi. 2007. Linking climate change modelling to impacts studies: Recent advances in downscaling techniques for hydrological modelling. Intl. $J$. Climatol. 27(12): 1547-1578.

Franczyk, J., and H. Chang. 2009. The effects of climate change and urbanization on the runoff of the Rock Creek basin in the Portland metropolitan area, Oregon, USA. Hydrol. Proc. 23(6): 805-815.

Gassman, P. W., M. R. Reyes, C. H. Green, and J. G. Arnold. 2007. The Soil and Water Assessment Tool: Historical development, applications, and future research directions. Trans. $A S A B E$ 50(4): 1211-1250.

Githui, F., W. Gitau, F. Mutua, and W. Bauwens. 2009. Climate change impact on SWAT-simulated streamflow in western Kenya. Intl. J. Climatol. 29(12): 1823-1834.

Gutowski, W. J., Jr., R. W. Arritt, S. Kawazoe, D. M. Flory, E. S. Takle, S. Biner, D. Caya, R. G. Jones, R. Laprise, L. R. Leung, L. O. Mearns, W. Moufouma-Okia, A. M. B. Nunes, Y. Qian, J. O. Roads, L. C. Sloan, and M. A. Snyder. 2010. Regional extreme monthly precipitation simulated by NARCCAP RCMs. J. Hydrometeorol. 11: 1373-1379, doi:10.1175/2010 JHM1297.1

IHA. 2009. Indicators of Hydrologic Alteration User's Manual. Ver. 7.1. Arlington, Va.: The Nature Conservancy.

IPCC. 2000. Special Report on Emission Scenarios. Cambridge, U.K.: Cambridge University Press

IPCC. 2007. Climate Change 2007: The Physical Science Basis. Contribution of Working Group I to the 4th Assessment Report of the Intergovernmental Panel on Climate Change. Cambridge, U.K.: Cambridge University Press.

IPCC. 2010. The IPCC data distribution centre. Intergovernmental Panel on Climate Change. Available at: www.ipcc-data.org. Accessed June 2010.

Jha, M., J. G. Arnold, P. W. Gassman, F. Giorgi, and R. R. Gu. 2006. Climate change sensitivity assessment on upper Mississippi River basin streamflows using SWAT. J. American Water Resour. Assoc. 42(4): 997-1015.

Juracek, K. E. 2002. Historical channel change along Soldier Creek, northeast Kansas. USGS Water-Resources Investigations Report 02-4047. Washington, D.C.: U.S. Geological Service.
Homer, C., C. Huang, L. Yang, B. Wylie, and M. Coan. 2004. Development of a 2001 national landcover database for the United States. Photogramm. Eng. Remote Sens. 70(7): 829-840.

Karl, T. R., J. M. Melillo, and T. C. Peterson, eds. 2009. Global Climate Change Impacts in the United States. Cambridge, U.K.: Cambridge University Press.

Moriasi, D. N., J. G. Arnold, M. W. Van Liew, R. L. Bingner, R. D. Harmel, and T. L. Veith. 2007. Model evaluation guidelines for systematic quantification of accuracy in watershed simulations. Trans. ASABE 50(3): 885-900.

NCDC. 2009. Climate-radar data inventories. Asheville, N.C.: National Climatic Data Center. Available at: www.ncdc. noaa.gov/oa/ncdc.html. Accessed November 2009.

Neitsch, S. L., J. G. Arnold, J. R. Kiniry, R. Srinivasan, and J. R. Williams. 2004. Soil and Water Assessment Tool Input/Output File Documentation, Version 2005. Temple, Tex.: USDA-ARS Grassland, Soil and Water Research Laboratory.

Neitsch, S. L., J. G. Arnold, J. R. Kiniry, and J. R. Williams. 2005. Soil and Water Assessment Tool Theoretical Documentation, Version 2005. Temple, Tex.: USDA-ARS Grassland, Soil and Water Research Laboratory, and Blackland Research and Extension Center.

Parajuli, P. B., K. R. Mankin, and P. L. Barnes. 2009a. Sourcespecific fecal bacteria modeling using Soil and Water Assessment Tool model. Bioresource Tech. 100(2): 953-963.

Parajuli, P. B., N. O. Nelson, L. D. Frees, and K. R. Mankin. 2009b. Comparison of AnnAGNPS and SWAT model simulation results in USDA-CEAP agricultural watersheds in south-central Kansas. Hydrol. Proc. 23(5): 748-763.

Siebenmorgen, C. B. 2010. Potential climate change impacts on hydrologic regimes in northeast Kansas. MS thesis. Manhattan, Kans.: Kansas State University, Department of Biological and Agricultural Engineering.

Siebenmorgen, C. B., A. Y Sheshukov, and K. R. Douglas-Mankin. 2010. Impacts of climate change on hydrologic indices in a northeast Kansas watershed. In Proc. 5th Conf. on Watershed Mgmt. to Meet Water Quality Standards and Emerging TMDLs. St. Joseph, Mich.: ASABE.

Somura, H., J. Arnold, D. Hoffman, I. Takeda, Y. Mori, and M. D. Luzio. 2009. Impact of climate change on the Hii River basin and salinity in Lake Shinji: A case study using the SWAT model and a regression curve. Hydrol. Proc. 23(13): 1887-1900.

Tuppad, P., K. R. Douglas-Mankin, T. Lee, R. Srinivasan, and J. G. Arnold. 2011. Soil and Water Assessment Tool (SWAT) hydrologic/water quality model: Extended capability and wider adoption. Trans. ASABE 54(5): 1677-1684.

USDA-NRCS. 2005. Soil data mart. Washington, D.C.: USDA Natural Resources Conservation Service. Available at: http://soildatamart.nrcs.usda.gov Accessed November 2009.

USDA-NRCS. 2007. 630.0700: Hydrologic soil groups. In National Engineering Handbook. Washington, D.C.: USDA Natural Resources Conservation Service.

USDA-NRCS. 2009. Geospatial data gateway. Washington, D.C.: Natural Resources Conservation Service. Available at: http://datagateway.nrcs.usda.gov. Accessed November 2009.

USGS. 2009. Daily streamflow for the nation. Washington, D.C.: U.S. Geological Service. Available at: http://nwis.waterdata. usgs.gov/nwis. Accessed November 2009.

Varanou, E., E. Gkouvatsou, E. Baltas, and M. Mimikou. 2002. Quantity and quality integrated catchment modeling under climate change with use of Soil and Water Assessment Tool model. J. Hydrol. Eng. 7(3): 228-244.

Wilby, R. L., S. P. Charles, E. Zorita, B. Timbal, P. Whetton, and L. O. Mearns. 2004. Guidelines for use of climate scenarios developed from statistical downscaling methods. Intergovernmental Panel on Climate Change. Available at: www.ipcc-data.org/guidelines/dgm_no2_v1_09_2004.pdf. Accessed 6 April 2011. 
Wilson, B. N., A. Y. Sheshukov, and R. Pulley. 2006. Chapter 3: Modeling algorithms of the WINDS model. In Erosion Risk Assessment Tool for Construction Sites. Research Report No. MN/RC-2006-27. St. Paul. Minn.: Minnesota Department of Transportation.

Winkler, J. A., G. S. Guentchev, Perdinan, P.-N. Tan, S. Zhong, M. Liszewska, Z. Abraham, T. Niedzwiedz, and Z. Ustrnul. 2011a. Climate scenario development and applications for local/ regional climate change impact assessments: An overview for the non-climate scientist. Part I: Scenario development using downscaling methods. Geography Compass 5(6): 275-300, doi: 10.1111/j.1749-8198.2011.00425.x.
Winkler, J. A., G. S. Guentchev, M. Liszewska, Perdinan, and P.-N. Tan. 2011b. Climate scenario development and applications for local/regional climate change impact assessments: An overview for the non-climate scientist. Part II: Considerations when using climate change scenarios. Geography Compass 5(6): 301-328, doi: 10.1111/j.1749-8198.2011.00426.x.

Zhang, X. C., M. A. Nearing, J. D. Garbrecht, and J. L. Steiner. 2004. Downscaling monthly forecasts to simulate impacts of climate change on soil erosion and wheat production. SSSA J. 68(4): 1376-1385.

Zhang, X., R. Srinivasan, and F. Hao. 2007. Predicting hydrologic response to climate change in the Luohe River basin using the SWAT model. Trans. ASABE 50(3): 901-910. 